\title{
Ogbanje Phenomenon; Mothers Perception, and Childhood Morbidity
}

\author{
Anyanwu Onyinye U', Ezeonu Chinonyelum T², Ezeanosike Obumneme B ${ }^{3}$, Okike Cliford O $^{4}$, Ibekwe Roland $C^{5}$
}

\begin{abstract}
Introduction: A cultural myth Ogbanje have existed among the Ibo people of Nigeria. These children may have morbidities that are manageable while some normal children may have to live with the stigma of being labelled such. The objective of this study was to assess mother's perception of ogbanje phenomenon and morbidity in ogbanje children. Material and Methods: This was a Cross-sectional study amongst mothers having the concept of "Ogbanje" children who were clinically examined. SPSS version 20.0 was used for data analysis. Variables were compared with $x 2$. $p<0.05$ was accepted as significant. Results: A total of $64.8 \%$ believed in "Ogbanje". Commonest presentation of "Ogbanje" was frequent illness (47.3\%). Only $12(3.3 \%)$ would seek orthodox care for ogbanje children. Examined "ogbanje" children had sicklecell anaemia, structural anomalies, and diabetes. Four (9.5\%; $\mathrm{n}=42$ ) children were normal. Conclusion: Ogbanje myth still exists in the minds of mothers and affects health seeking behaviour. Ogbanje children may have manageable illness and sometimes may be normal.
\end{abstract}

Key words: Ogbanje, Mother's perception, Childhood morbidity.

\section{Introduction}

n Nigeria the need to reduce infant and child morbidity and mortality is one of the greatest challenges confronting the federal government. Although analyses of recent trends show that Nigeria is making some progress in reducing infant and under-five mortality rates, the pace still remains slow ${ }^{1}$. These deaths are mostly preventable or treatable at low cost, however ignorance, ${ }^{2}$ poverty ${ }^{3}$ and cultural beliefs ${ }^{4}$ have remained the key factors underling childhood morbidity and mortality in Nigeria. Many cultural and religious beliefs exist in Nigeria and amongst the Igbo tribe of Nigeria. One of such beliefs is the "Ogbanje" phenomenon. Ogbanje is an expression of the Igbo tribe of Nigeria which means a repeater ${ }^{5}$. It describes a magical child who repeatedly dies, re-enters the mother's womb only to be born again ${ }^{5,6}$. The ogbanje spirit is said to be a malevolent spirit which plagues the family with misfortune and grief ${ }^{7}$.

Ogbanje children are believed to be committed to a shortened life span to the deities. With this commitment they receive a desirable appearance or outstanding psychic talent but at the expense of
${ }^{1}$ Anyanwu Onyinye U, FWACP. FMCPead. Consultant Paediatrician IBEKWE ROLAND C, FMCPead, Consultant Paediatric Neurologist. ${ }^{2}$ Ezeonu Chinonyelum T, FMCPead, Consultant Community Paediatrician. ${ }^{3}$ Ezeanosike Obumneme B, FWACP, Consultant Paediatrician, ${ }^{4}$ Okike Cliford $\mathrm{O}$, FWACP. Consultant Paediatrician, ${ }^{5}$ lbekwe Roland C, FMCPead. Consultant Paediatric Neurologist. All from the Federal Teaching Hospital Abakaliki, Ebonyi State, Nigeria.

\section{Address for correspondence \\ Anyanwu Onyinye Uchenna \\ Department of Paediatrics. \\ Federal Teaching Hospital Abakaliki, \\ Ebonyi State, Nigeria. \\ Tel No; +2348033230292 \\ E-mail:onyinyeanyanwugc@gmail.com}

\section{How to cite}

Anyanwu Onyinye $U$, Ezeonu Chinonyelum $\mathrm{T}$, Ezeanosike Obumneme B, Okike Cliford O, Ibekwe Roland C. Ogbanje Phenomenon; Mothers Perception, and Childhood Morbidity. J Nepal Paediatr Soc 2017;37(1):79-82.

doi:http://dx.doi.org/10.3126/jnps.v37i1.16373

This work is licensed under a Creative Commons Attribution 3.0 License. 
human relationships ${ }^{8}$. They are said to have spiritual companions with which they always communicate supernaturally resulting in hallucinatory experiences or dreams ${ }^{8}$. They are also said to arrange to die at an agreed time of a brief illness usually at about puberty or a significant day of their life such as their birthday ${ }^{5,9}$.

It has since been a literary and cultural phenomenon, however is of clinical interest since the children may have some symptomatology pointing to a clinical entity ${ }^{5}$. Also the belief of mothers on the phenomenon may affect their health seeking behaviour ultimately affecting morbidity and mortality rates. The modern day lgbo mother may no longer patronise native doctors who heal with voodoo, but may patronize herbal practitioners where they receive herbs of which their content and dosages are unknown. Belief in cosmic powers and supernatural causes to ill-health may also make mothers seek help at churches and prayer houses rather than seek orthodox help ${ }^{10}$.

It was the aim of the researchers to assess mother's perception of the ogbanje phenomenon as well as childhood morbidity in ogbanje children in Abakaliki.

\section{Material and Methods}

The Igbos are one of the major tribes of the country and are found in the South-Eastern parts of Nigeria ${ }^{11}$. Ebonyi state, one of the Igbo speaking states has its capital at Abakaliki. Its inhabitants are of different educational attainments and religion.

A community based convenient sample of mothers were recruited on a house-to-house basis. Informed written consent was obtained from participants before commencement of the study.

A researcher administered questionnaire was used for data collection. The responses given by respondents of their socio-demography and beliefs of ogbanje were recorded. Socioeconomic stratification was done using parents highest educational attainment and occupation $^{12}$.

Children who were labelled Ogbanje by their parents, had history and physical examination done. Investigations such as Haemoglobin electrophoresis to determine the $\mathrm{Hb}$ genotype, and a random blood sugar were done after a written consent was obtained. Diagnosis of Autistic disorder and attention deficit hyperactivity disorder were made using the DSM IV/V classification. Those found to have abnormalities were referred to the appropriate subspecialty in Federal Teaching Hospital Abakaliki (FETHA) for management.

Data analysis was done using the statistical package for social sciences (SPSS) version 20. Descriptive statistics were done and results were presented as means and proportions. The chi-square test was used to find associations between variables. A significant level of $p<0.05$ was accepted as significant.

\section{Results}

A total of 364 respondents were interviewed. Their mean age was $32.88+7.21$ years. Upper, middle and lower socioeconomic classes were $33.0 \%, 24.2 \%$ and $42.9 \%$ respectively. Roman Catholics consisted of $50.5 \%$, and majority resided in the rural area (54.9\%). The total number of children for each mother ranged from 1 to 12 , with a mean of $3.79+2.99$.

All respondents had heard about Ogbanje phenomenon, 236(64.8\%) believed in it. Eighty eight $(24.2 \%)$ had an Ogbanje child of which $72(19.8 \%)$ responded that the child was living while 16(4.4) responded that the child had died. The commonest presumed presentation for Ogbanje were frequent illness $(47.3 \%)$ (Table 1).One hundred and twenty four(34.1\%) of respondents believed that Ogbanje children should be treated specially such as not participating in house chores $40(11.0 \%)$, being given all they desire 40(11.0\%), and should never be annoyed 36(9.9). When an Ogbanje child is ill, 136(37.4\%) believed it should be sought at a church/prayer house, and $44(12.1 \%)$ from a traditional healer. Twelve(3.3\%) responded that only orthodox care should be sought. There was no significant difference in mothers perceptions and health-seeking behaviour when they were compared with maternal age, education and socioeconomic status ( $p=0.3,0.08$, and 0.06$)$.

Of the living Ogbanje children, 52 were females while 20 were males with a mean age of $5.62+2.93$ years. Those from the upper socioeconomic class were $32(44.4 \% ; n$ 72), $8(11.2)$ were of the middle class while $32(44.4 \%)$ were from the lower class. Majority were of Pentecostal denomination (44.5\%), 55.6\% of respondents had urban residence. Thirty $(41.7 \%)$ however, declined further investigation out of fear of the deity. Forty-two children were then clerked and examined. The various morbidities identified are as shown in Table 2. 
Table 1: Responses of Participants Concerning Ogbanje

\begin{tabular}{|c|c|c|}
\hline Variable & Response & Frequency (\%) \\
\hline Have you heard about ogbanje? & Yes & $364(100.0)$ \\
\hline \multirow{2}{*}{ Do you believe there are children who are ogbanje? } & Yes & $236(64.8)$ \\
\hline & No & $128(35.2)$ \\
\hline \multirow{2}{*}{ Have you ever had an ogbanje child? } & Yes & $88(24.2)$ \\
\hline & No & $276(75.8)$ \\
\hline \multirow{2}{*}{ Is the child alive? } & Yes & $72(19.8)$ \\
\hline & No & $16(4.4)$ \\
\hline \multirow{5}{*}{ What are the common presentations of ogbanje? } & Evidence of deformity from past life & $36(9.9)$ \\
\hline & Frequent illness & $172(47.3)$ \\
\hline & $\begin{array}{l}\text { Non response of illnesses to orthodox } \\
\text { medicine }\end{array}$ & $8(2.2)$ \\
\hline & $\begin{array}{l}\text { Repeated death with verification by } \\
\text { a dibia }\end{array}$ & $52(14.3)$ \\
\hline & Don't know & $96(26.4)$ \\
\hline \multirow{6}{*}{ Where should care be sought when such children are ill? } & Hospital alone & $12(3.3)$ \\
\hline & Traditional healer alone & 136(37.4) \\
\hline & Church/prayer house alone & $136(37.4)$ \\
\hline & Traditional + Orthodox & $40(11.0)$ \\
\hline & Traditional + Church & $36(9.9)$ \\
\hline & Orthodox + Church & $4(1.1)$ \\
\hline
\end{tabular}

Table 2: Mobidities Identified in The Living "Ogbanje" Children

\begin{tabular}{lcc}
\hline \multicolumn{1}{c}{ Diagnosis } & Morbidity & Frequency (\%) \\
\hline SICKLE CELL ANEMIA & - & $15(35.7)$ \\
\hline STRUCTURAL DEFFECT & - & - \\
& MISSING DIGITS & - \\
\cline { 2 - 3 } & CLUB FOOT & - \\
\hline & SCOLIOSIS & $12(28.6)$ \\
PSYCHIATRIC & TOTAL & - \\
& HYPERACTIVITY & - \\
\hline NO OBVIOUS ANOMALLY & AUTISM & $10(23.8)$ \\
\hline DIABETES & TOTAL & $4(9.5)$ \\
\hline
\end{tabular}

\section{Discussion}

Children who were frequently ill are most likely going to be identified as Ogbanje hence shall be treated as such with a lot of pampering and lack of discipline while holding their mothers in fear that they may soon die leaving her with the pains of going through child birth again. It is worthy of note that the age long phenomena of Ogbanje still exists in the minds of people despite improved literacy and socioeconomic status. This may have adverse effects on the child as it affects healthseeking behaviour of mothers as shown in this study.

Current study has shown that majority of these Ogbanje children had sickle cell anaemia which could be managed. Nevertheless, respondents were most likely to seek help from churches and traditional healers than from a hospital. Such practices may result in increased morbidity and mortality in children. Some of the Ogbanje children were found to be normal.

\section{Conclusion}

The age-long ogbanje phenomenon still exists in the minds of mothers affecting their health-seeking behaviour and invariable child health. These Ogbanje children may have preventable or manageable illness and sometimes may be normal. Increased awareness campaign directed at the community would help dissipate the fear in our populace of this phenomenon. 


\section{References}

1. Maternal and child health. UNICEF. http://www.unicef. org/nigeria/children_1926.html (Assessed 19th july 2016)

2. Bradley AK, Gilles HM. Malunfashi endemic diseases research project, 21 pointers to causes of death in the Malunfashi area, Northern Nigeria. Ann Trop Med Parasitol 1984; 78: 265-271.

3. Owumi BE, Ezeogu A. Poverty and HIVIAIDS patient management in Swaziland: A case study of known HIVIAIDS Patients. In:Munyae M, Pempelani M(eds.). Debt Relief Initiatives and Poverty Alleviation. Lessons From Africa. African Century Publications, South Africa 2003. $189-196$.

4. Iyun BF, Oke EA. Ecological and cultural barriers to treatment of childhood diarrhea in riverine areas of Ondo state, Nigeria. Soc Sci Med 2000;50:953-64.

5. Ilechukwu STC. Ogbanje/abiku: A culture-bound construct of childhood and family pathology in West Africa. Psychopathologie Africaine 1990/1991; 23: 2751.
6. Ilechukwu STC. Ogbanje/abiku and cultural conceptualizations of psychopathology in Nigeria. Mental Health, Religion \& Culture 2007;10(3):239-55

7. Ebigbo PA, Anyaegbunam B. The problem of student involvement in the mermaid cult - a variety of belief in reincarnation (ogbanje) in a Nigerian secondary school. J African Psychol 1988;1:1-14.

8. Achebe C. Things fall apart. London: Heinemann. 1958.

9. Achebe, C. The world of ogbanje. Enugu, Nigeria: Fourth Dimension.1986.

10. Azubuike JC, Egbonu I. Socio-cultural and other determinants of health and disease in Children in the tropics. In: Azubuike JC, Nkanginieme KEO, editors. Pediatrics Child Health in a Tropical Region. $2^{\text {nd }}$ ed. Owerri: African Educational Services; 2007. p. 4-11.

11. Ogbaa K. Igbo. Heritage Library of African Peoples. 2nd ed. New York: Rosen Publishing Group. 2010.

12. Oyedeji GA. Socioeconomic and cultural background of hospitalized children in llesa. Niger J Paediatr 1985;12:111-117. 